\title{
Clinical profile of probable cluster headache without ipsilateral autonomous symptoms
}

\author{
N Imai \\ From The European Headache and Migraine Trust International Congress \\ London, UK. 20-23 September 2012
}

\section{Introduction}

Cluster headaches $(\mathrm{CH})$, characterized by strictly unilateral pain localized in or around the eye and accompanied by ipsilateral autonomic features, are the most painful form of primary headache. Probable cluster headache $(\mathrm{PCH})$ is a subtype of $\mathrm{CH}$ fulfilling all but one diagnostic criteria for it: for example, with no ipsilateral autonomic features. $\mathrm{CH}$ is associated with severe pain and has a considerable impact on social functioning and quality of life. Like $\mathrm{CH}$, $\mathrm{PCH}$ without ipsilateral autonomic features (PCHWOIAF) may be associated with severe pain and considerable impact, but PCHWIAF has not been studied. The present study aimed to clarify the clinical profile of PCHWIAF.

\section{Methods}

Seven patients who had been diagnosed with PCHWOIAF according to the 2nd edition of the International Classification of Headache Disorders were compared with 86 patients with $\mathrm{CH}$. We collected data on laterality and location of headache, pain intensity, impact, additional features (sense of restlessness during the attacks, nausea, vomiting, photophobia and phonophobia), duration of attacks, and time of onset of attacks.

\section{Results}

Pain occurred in the forehead, occipital regions, and vertex significantly more often in patients with PCHWOIAF than in patients with $\mathrm{CH}$. There were no significant differences between patients with PCHWOIAF and $\mathrm{CH}$ in the mean age at first consultation, mean age of onset, the ratio of males to females, laterality of headache, pain intensity, impact, additional features, duration of attacks, and time of onset of attacks.

Japanese Red Cross Shizuoka Hospital, Japan

\section{Conclusion}

The impact of PCHWOIAF is similar to that of $\mathrm{CH}$. Patients with PCHWOIAF should receive the same level of treatment as patients with cluster headaches.

Published: 21 February 2013

\section{Reference}

1. Headache Classification Subcommittee of the International Headache Society: The international classification of headache disorders. Cephalalgia 2004, 24(Suppl 1):60-63.

\section{doi:10.1186/1129-2377-14-S1-P43}

Cite this article as: Imai: Clinical profile of probable cluster headache without ipsilateral autonomous symptoms. The Journal of Headache and Pain 2013 14(Suppl 1):P43.

\section{SpringerOpen $^{\odot}$}

C 2013 Imai; licensee Springer. This is an Open Access article distributed under the terms of the Creative Commons Attribution License (http://creativecommons.org/licenses/by/2.0), which permits unrestricted use, distribution, and reproduction in any medium, provided the original work is properly cited.
Submit your manuscript to a SpringerOpen ${ }^{\circ}$ journal and benefit from:

- Convenient online submission

- Rigorous peer review

- Immediate publication on acceptance

- Open access: articles freely available online

- High visibility within the field

Retaining the copyright to your article

Submit your next manuscript at $>$ springeropen.com 